\title{
PENGEMBANGAN BAHAN AJAR BERBASIS PROJECT BASED LEARNING BERBANTUAN SOFTWARE GEOGEBRA
}

\author{
Dhia Octariani ${ }^{1}$, Isnaini Halimah Rambe ${ }^{2}$ \\ Universitas Islam Sumatera Utara \\ 12hia88octariani@gmail.com, 2isnainirambey89@gmail.com
}

\begin{abstract}
This research is a learning device development research that will be used in learning with the Project based Learning (PjBL) model with the help of technology, in this case using Geogebra software. Geogebra Software is a dynamic mathematical software that combines geometry, algebra and calculus can be used as a tool in mathematical learning. Geogebra is a special mathematical program that can be used as a medium for learning mathematics. This research was conducted in one of the high schools in Deli Serdang Regency. Development of learning is done gradually in accordance with step $4 D$, then the researchers simplify the changing of the four stages (4D) into three stages (3D) is defining, designing, and development.
\end{abstract}

Keywords: Teaching Materials, Project Based Learning (PjBL), Geogebra Software

\begin{abstract}
Abstrak. Penelitian ini merupakan penelitian pengembangan perangkat pembelajaran yang akan digunakan dalam pembelajaran dengan model Projectbased Learning (PjBL) dengan bantuan teknologi, dalam hal ini menggunakan software Geogebra. Software Geogebra adalah software matematika dinamis yang menggabungkan geometri, aljabar, dan kalkulus dapat digunakan sebagai alat bantu dalam pembalajaran matematika. Geogebra merupakan program khusus matematika yang dapat digunakan sebagai media pembelajaran matematika. Penelitian ini dilakukan di salah satu sekolah menengah atas di Kabupaten Deli Serdang. Pengembangan pembelajaran dilakukan bertahap sesuai dengan langkah 4D, yang kemudian para peneliti menyederhanakan dengan mengubah dari empat tahap (4D) menjadi tiga tahap (3D) yaitu pendefinisian, perancangan, dan pengembangan.
\end{abstract}

Kata Kunci: Bahan Ajar, Model Project Based Learning (PjBL), Software Geogebra

\section{PENDAHULUAN}

Salah satu masalah yang dihadapi dunia pendidikan adalah lemahnya proses pembelajaran. Dalam proses pembelajaran, anak kurang didorong untuk mengembangkan kemampuan berpikir. Berdasarkan Peraturan Menteri Pendidikan Nasional (Permendiknas) nomor 41 tahun 2007 tentang Standar Proses, yang mengatur tentang perencanaan proses pembelajaran yang mensyaratkan bagi pendidik pada satuan pendidikan untuk mengembangkan Rencana Pelaksanaan Pembelajaran (RPP). Salah satu elemen dalam RPP adalah sumber belajar. Berdasarkan hal tersebut guru diharapkan untuk mengembangkan bahan ajar sebagai salah satu sumber belajar. Kemampuan guru dalam merancang bahan ajar menjadi hal yang sangat berperan dalam menentukan keberhasilan proses belajar dan pembelajaran melalui sebuah bahan ajar.

Bahan ajar adalah segala bentuk bahan yang digunakan guru/instruktur dalam melaksanakan kegiatan belajar mengajar dimaksud bisa berupa bahan tertulis maupun bahan tidak tertulis. Bahan ajar memungkinkan siswa dapat mempelajari suatu kompetensi atau kompetensi dasar secara runtut dan sistematis sehingga secara akumulatif mampu menguasai semua kompetensi secara utuh dan terpadu. Bahan ajar merupakan informasi, alat dan teks yang diperlukan guru/instruktur untuk perencanaan dan penelaahan implementasi pembelajaran. Bahan ajar adalah segala bentuk bahan atau materi yang disusun secara sistematis dan digunakan untuk membantu guru atau instruktur dalam melaksanakan kegiatan belajar mengajar sehingga tercipta lingkungan atau suasana yang memungkinkan siswa untuk belajar. 
Bahan ajar atau teaching-material yang dimaksud bisa berupa bahan tertulis maupun bahan tidak tertulis. Kelompok bahan ajar terdiri dari kelompok media tulis, audio visual, elektronik dan interaktif terintegrasi. Sebuah bahan ajar paling tidak mencakup petunjuk belajar (petunjuk siswa/guru), kompetensi yang akan dicapai, informasi pendukung, latihan-latihan, petunjuk kerja yang dapat berupa lembar kerja (LK), dan evaluasi. Bahan ajar atau materi pembelajaran (instructional materials) secara garis besar terdiri dari pengetahuan, keterampilan, dan sikap yang harus dipelajari siswa dalam rangka mencapai kompetensi yang telah ditentukan. Secara terperinci, jenis-jenis materi pembelajaran terdiri dari pengetahuan (fakta, konsep, prinsip, prosedur), keterampilan, dan sikap atau nilai.

Berdasarkan beberapa pengertian bahan ajar di atas dapat ditarik kesimpulan bahwa bahan ajar merupakan segala macam bentuk bahan berupa media tulis, media audio-visual, elektronik, interaksi terintegrasi yang tediri dari pengetahuan, ketrampilan, dan sikap yang harus dipelajari siswa untuk membantu guru dalam proses belajar mengajar dalam rangka mencapai kompetensi yang telah ditentukan.

Dalam proses pembelajaran guru dituntut kreatif dalam penyampaian pembelajaran sehingga siswa tidak merasa bosan. Maka dari itu dibutuhkan pengelolaan kelas yang baik dari guru. Dengan pengelolaan kelas yang baik maka akan menarik minat dan kemauan siswa dalam mengikuti bahan pelajaran yang disampaikan guru. Minat dan kemauan peserta didik dalam belajar tergantung dengan bagaimana cara guru dalam menyampaikan bahan pelajaran. Apabila cara mengajar guru monoton maka akan membuat siswa jenuh untuk mengikuti pelajaran tersebut. Karena pada dasarnya dalam pelaksanaan pembelajaran dibutuhkan metode pembelajaran yang efektif.

Selain memilih bahan ajar yang tepat, untuk melakukannya seorang guru harus memilih suatu pendekatan atau model pembelajaran yang tepat pula, agar siswa benarbenar merasakan makna dari materi yang mereka pelajari. Salah satunya adalah dengan model pembelajaran Project Based Learning (PjBL). Menurut Hanafiah dan Suhana (2009:30) model pembelajaran Project Based Learning adalah pendekatan pembelajaran yang memperkenankan peserta didik untuk bekerja mandiri dalam mengkonstruksi pembelajarannya dan mengkulminasikannya dalam produk nyata. Sedangkan menurut Trianto (2014:42) Project Based Learning adalah sebuah model atau pendekatan pembelajaran yang inovatif, yang menekankan belajar kontekstual melalui kegiatankegiatan yang kompleks.

Menurut Wena (2014:144) model pembelajaran Project Based adalah model pembelajaran yang memberikan kesempatan kepada guru untuk mengelola pembelajaran dikelas dengan melibatkan kerja proyek. Kerja proyek merupakan suatu bentuk kerja yang memuat tugas-tugas kompleks berdasarkan kepada pertanyaan dan permasalahan yang sangat menantang dan menuntun peserta didik untuk merancang, memecahkan masalah, membuat keputusan, melakukan kegiatan investigasi, serta memberikan kesempatan peserta didik untuk bekerja secara mandiri.

Dari beberapa pendapat dapat disimpulkan bahwa model pembelajaran Project Based Learning merupakan model pembelajaran inovatif yang melibatkan kerja proyek dimana peserta didik bekerja secara mandiri dalam mengkonstruksi pembelajarannya dan mengkulminasikannya dalam produk nyata. Dalam kerja proyek memuat tugas-tugas kompleks berdasarkan kepada pertanyaan dan permasalahan yang sangat menantang dan menuntun peserta didik untuk merancang, memecahkan masalah, membuat keputusan, melakukan kegiatan investigasi, serta memberikan kesempatan peserta didik untuk bekerja secara mandiri.

Project based learning memiliki karakteristik yang membedakan model yang lain. Karakteristik tersebut, antara lain:

1. Centrality pada project based learning, proyek menjadi pusat dalam pembelajaran. 
2. Driving question Project based learning difokuskan pada pertanyaan atau masalah yang mengarahkan siswa untuk mencari solusi dengan konsep atau prinsip ilmu pengetahuan yang sesuai.

3. Constructive Investigation pada project based learning, siswa membangun pengetahuannya dengan melakukan investigasi secara mandiri (guru sebagai fasilitator).

4. Autonomy Project based learning menuntut student centered, siswa sebagai problem solver dari masalah yang dibahas.

5. Realisme Kegiatan siswa difokuskan pada pekerjaan yang serupa dengan situasi yang

6. sebenarnya. Aktifitas ini mengintegrasikan tugas otentik dan menghasilkan sikap profesional (Thomas, 2000).

Menurut Rais (2010:8-9) langkah-langkah model pembelajaran Project Based Learning adalah sebagai berikut: 1) Membuka pelajaran dengan suatu pertanyaan menantang (start with the Essential question); 2) Merencanakan proyek (design a plan for the project); 3Menyusun jadwal aktivitas (create a schedule); 4) Mengawasi jalannya proyek (monitor the students and the progress of the project); 5) Penilaian terhadap produk yang dihasilkan (assess the outcome); dan 6) Evaluasi (evaluate the experience)

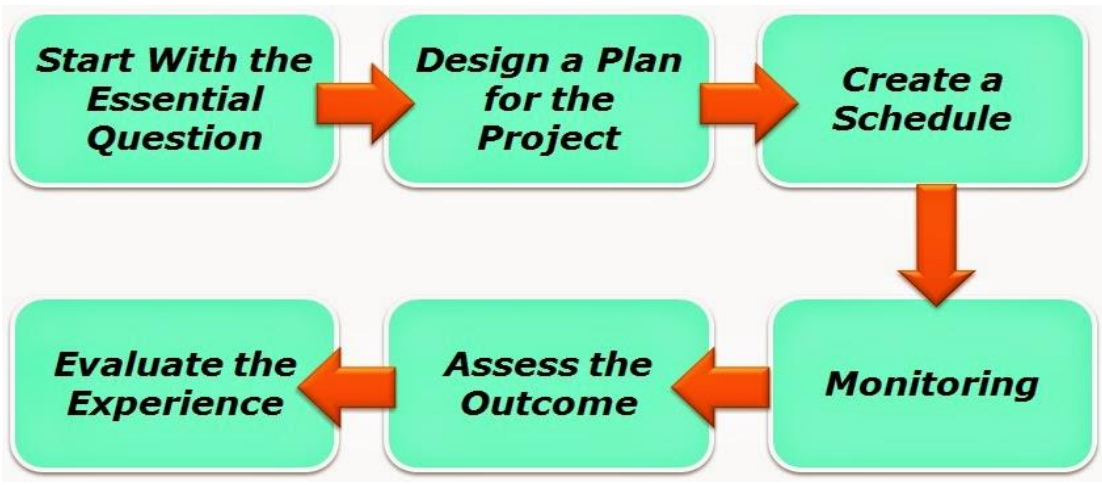

Gambar 1. Skema Langkah Model Pembelajaran PjBL

Model pembelajaran berbasis proyek (project based learning) adalah sebuah model pembelajaran yang menggunakan proyek (kegiatan) sebagai media 2dalam kegiatan (proyek) ini siswa melakukan eksplorasi, penilaian, interpretasi, dan sintesis informasi untuk memperoleh berbagai hasil belajar (kognitif, afektif, dan psikomotorik). The Council of Teachers of Mathematics (NCTM) Principles and Standars for School Mathematics menjelaskan bahwa pembelajaran berbasis proyek mempunyai ciri-ciri bahwa siswa dapat memilih topik dan/atau proyek presentasi atau produk, menghasilkan produk akhir misal presentasi, rekomendasi untuk memecahkan masalah yang terkait dengan dunia nyata, melibatkan berbagai disiplin ilmu, bervariasi dalam durasi waktu, menampilkan guru dalam peran fasilitator.

Perangkat pembelajaran yang akan dikembangkan adalah perangkat pembelajaran berbasis teknologi. Penelitian ini mencoba untuk mengembangkan bahan ajar dengan bantuan teknologi, dalam hal ini menggunakan software geogebra. Geogebra adalah software matematika dinamis yang menggabungkan geometri, aljabar, dan kalkulus dapat digunakan sebagai alat bantu dalam pembalajaran matematika. Geogebra merupakan program khusus matematika yang dapat digunakan sebagai media pembelajaran matematika.

Menurut Hohenwarter, 2008:12) Geogebra adalah software matematika dinamis yang menggabungkan geometri, aljabar, dan kalkulus dapat digunakan sebagai alat bantu dalam pembalajaran matematika. Software ini dikembangkan untuk proses belajar matematika di sekolah oleh Markus Hohenwarter di Universitas Florida Atlantik. Di satu sisi, GeoGebra 
adalah sistem geometri dinamik. kita dapat melakukan konstruksi dengan titik, vektor, ruas garis, garis, irisan kerucut, begitu juga dengan fungsi, dan mengubah hasil konstruksi selanjutnya. Selain itu geogebra adalah sebuah softwere yang sangat membantu peserta didik atau para guru dalam mengerjakan tugas atau pembelajaran Matematika yang berkaitan dengan geometri, aljabar, tabel, grafik, statistik dan kalkulus bisa lebih mudah menggunakan software ini.

\section{METODE}

Thiagarajan, Semmel dan Semmel (1974) mengemukakan pengembangan pembelajaran dilakukan bertahap sesuai dengan langkah 4D, yang kemudian para peneliti menyederhanakan dengan mengubah dari empat tahap (4D) menjadi tiga tahap (3D), yakni: pendefinisian (define), perancangan (design) dan pengembangan (develop).

a. Pendefinisian (Define)

Kegiatan pada tahap ini adalah menetapkan dan mendefinisikan syarat-syarat pembelajaran diawali dengan analisis untuk menentukan tujuan dan kendala untuk materi pembelajaran, sebagai berikut:

1) Analisis Awal

Tahap ini adalah mempelajari masalah yang dihadapi guru dalam menentukan kemungkinan alternatif bahan ajar yang lebih efektif dan efisien.

2) Analisis Siswa

Tahap ini adalah mempelajari kebutuhan siswa melalui kompetensi yang akan dipelajari.

3) Analisis Tugas

Tahap ini adalah mengidentifikasi keterampilan utama yang diperoleh siswa sesuai tugas yang terkandung dalam bahan ajar.

4) Analisis konsep

Tahap ini adalah mengidentifikasi konsep- konsep utama yang akan diajarkan.

5) Spesifikasi Tujuan

Spesifikasi tujuan dilakukan untuk menentukan tujuan pembelajaran yang sesuai dengan materi yang akan dipelajari dan juga sebagai dasar dalam menentukan konten bahan ajar.

b. Perancangan (Design)

Kegiatan pada tahap ini adalah mendesain prototype bahan ajar setelah menentukan sekumpulan tujuan dan kendala-kendala yang dihadapi pada bahan ajar yang akan dikembangkan, sebagai berikut:

1) Penyusunan Tes Acuan Kriteria Pada tahap ini, peneliti menyusun instrumen yang digunakan untuk menilai kelayakan bahan ajar yang akan dikembangkan (instrumen validasi), serta menyusun instrumen untuk menilai keterampilan proses siswa (instrumen tes).

2) Pemilihan Media Memilih media yang cocok untuk menunjukan pemahaman isi pembelajaran. Proses ini meliputi penyesuaian antara analisis tugas dan konsep, karakterstik peserta didik, sumber bahan ajar dan rencana penyebaran dengan berbagai atribut media yang berbeda.

3) Pemilihan Format Bahan Ajar, Pengumpulan Referensi dan Desain Awal Pemilihan format bahan ajar yang akan dikembangkan sesuai dengan kebutuhan siswa dan sesuai dengan pembelajaran matematika. Selanjutnya mengumpulkan berbagai referensi yang berkaitan dengan materi yang akan diringkas dalam bahan ajar. Berbagai referensi digunakan agar tidak ada kesalahan konsep dalam bahan ajar yang dikembangkan. 
4) Desain Bahan Ajar Peneliti mendesain bahan ajar semenarik mungkin agar siswa termotivasi membacanya dan mempelajarinya sehingga terbentuk menjadi Draft I.

c. Pengembangan (Develop)

Tahap pengembangan adalah tahap implementasi dari perencanaan produk yang telah dilakukan pada tahap sebelumnya.Tujuan dari tahap ini adalah untuk menghasilkan produk akhir bahan ajar. Adapun langkah yang dilakukan adalah sebagai berikut:

1) Penilaian Ahli Penilaian adalah tahap yang penting dalam mengembangkan bahan ajar, sebab melalui tahapan ini Bahan ajar yang dikembangkan diuji kelayakannya oleh ahli. Masukan, saran, serta perbaikan dari hasil validasi selanjutnya digunakan untuk memperbaiki bahan ajar (Draft II) sehingga didapatkan bahan ajar (Draft III) yang sudah direvisi sebelum diuji-cobakan.

2) Uji Coba Pengembangan Pada tahap ini, peneliti melakukan uji coba lapangan menggunakan bahan ajar Draft III. Adapun tujuan dari uji coba lapangan adalah untuk mengetahui peningkatan keterampilan proses siswa setelah menggunakan bahan ajar hasil pengembangan.

3) Revisi Berdasarkan data hasil uji coba maka peneliti melakukan evaluasi dan revisi untuk memperbaiki bahan ajar (Draft III) sehingga dihasilkan produk akhir bahan ajar (Draft IV).

4) Produk Akhir Bahan ajar siap untuk diseminasi.

\section{HASIL DAN PEMBAHASAN}

Validasi ahli merupakan kegiatan validasi produk yang dilakukan sebelum diuji cobakan secara terbatas. Validasi dilakukan dengan cara menilai bahan ajar yang diberikan kepada para ahli, yakni dosen pendidikan matematika di UISU dan guru sekolah SMA Swasta Istiqlal. Hasil penilaian dapat dilihat pada tabel 1.

Tabel 1. Hasil Validasi Para Ahli terhadap Bahan Ajar

\begin{tabular}{clcc}
\hline No & Materi Validasi & Rata-Rata Hasil Validasi & Keterangan \\
\hline 1 & RPP & 3,25 & Baik \\
\hline 2 & LKS & 3,2 & Baik \\
\hline 3 & Modul Geogebra & 3,5 & Baik \\
\hline 4 & Soal Tes & Valid & Tanpa Revisi \\
\hline
\end{tabular}

Dari hasil validasi di atas menunjukan hasil baik dan valid, serta dapat digunakan untuk diuji cobakan pada para siswa. Salah satu kegiatan yang dirancang pada bahan ajar ini adalah menyelesaikan dan menemukan konsep lingkaran dan mampu mengaplikasikannya pada software geogebra. Pada kegiatan tersebut peneliti ingin melihat respon siswa dalam menyelesaikan masalah yang diberikan dan mengetahui respon siswa terhadap pembelajaran berbasis PjBL berbantuan Software Geogebra.

\section{KESIMPULAN}

Kesimpulan yang diperoleh berdasarkan hasil penilaian dari para ahli adalah bahan ajar yang sedang dikembangkan ini memperoleh hasil yang baik yaitu rata-rata di atas 3,2. Sehingga bahan ajar ini layak digunakan sebagai salah satu sumber belajar pada kegiatan belajar-mengajar. Penelitian selanjutnya yang dapat dilakukan adalah tahap diseminasi, yakni menggunakan bahan ajar tersebut sebagai sumber belajar-mengajar. Penelitian lebih lanjut dapat dilakukan untuk melihat dampak pembelajaran menggunakan Software Geogebra terhadap beberapa kemampuan matematis lainnya, misal: berpikir kreatif, atau kemampuan matematis yang lain. 


\section{UCAPAN TERIMA KASIH}

Pada kesempatan ini peneliti mengucapkan terima kasih kepada: Direktorat Riset dan Pengabdian Masyarakat Direktorat Jenderal Penguatan Riset dan Pengembangan Kementerian Riset, Teknologi, dan Pendidikan Tinggi yang telah memeberikan bantuan dana, Universitas Islam Sumatera Utara, LP Universitas Islam Sumatera Utara dan lokasi penelitian yang telah memberikan izin selama proses pelaksanaan penelitian.

\section{DAFTAR PUSTAKA}

Sani, R. A. 2014. Pembelajaran Saintifik Untuk Implementasi Kurikulum 2013. Jakarta: Bumi Aksara.

Abidin, Y. 2014. Desain Sistem Pembelajaran dalam Konteks Kurikiulum 2013. Bandung: Refika Aditama.

Akbar, S., Sriwiyana, H. 2010. Pengembangan Kurikulum dan Pembelajaran. Yogyakarta: Cipta Media

Arifin, Z. 2012. Penelitian Pendidikan: Metode dan Paradigma Baru. Bandung: Remaja Rosdakarya.

Widjajanti, E. 2011. Kualitas Lembar Kerja Siswa. Yogyakarta: UNY.

Hartono, dkk. Pengembanagn Perangkat Pembelajaran Model Problem Based Learning untuk Meningkatkan Kemampuan Berpikir Kreatif. Jurnal of Primary Education: Semarang

Munandar, U. 2009. Pengembangan Kreativitas Anak Berbakat. Jakarta: Rineka Cipta

Purwanto. 2011. Statistik Penelitian. Yogyakarta: Pustaka Pelajar.

Setyosari, P. 2013. Metode Penelitian Pendidikan dan Pengembangan. Jakarta:Kencana.

Sudijono, A. 2005. Pengantar Evaluasi Pendidikan. Jakarta: Raja Grafindo Persada.

Sugiyono. 2013. Metode penelitian kuantitatif kualitatif dan RnD. Bandung: Alfabeta.

Widyantini, T. 2014. Artikel: Penerapan Model Project Based Learning (Model Pembelajaran Berbasis Proyek) dalam Materi Pola Bilangan Kelas VII. Yogyakarta: P4TK Matematika.

Widoyoko, E. P. 2008. Evaluasi Program Pembelajaran: Panduan Praktis Bagi Pendidik dan Calon Pendidik. Yogyakarta: Pustaka Pelajar. 